\title{
Causal Relationship Between Air Transport and Economic Growth: Evidence from Panel Data for High, Upper-Middle, Lower-Middle and Low-Income Countries
}

\author{
Kasım Kiracı ${ }^{1}$, Mahmut Bakır ${ }^{*}$ \\ ${ }^{1}$ Iskenderun Technical University, Hatay, Turkey \\ ${ }^{2}$ Anadolu University, Eskişehir, Turkey \\ ${ }^{*}$ Corresponding author: mahmutbakir@anadolu.edu.tr
}

\begin{abstract}
This study aims to find out the causal relationship between air transport and economic growth based on income level. To this end, selected countries with high-income, uppermiddle-income, lower-middle-income, and low-income levels were included in the analyses for this study. Focusing on the 1990-2016 period, a total of 70 countries were classified according to their income levels and were analyzed empirically. In the study, panel causality analyzes by Kónya (2006) and Emirmahmutoğlu \& Köse (2011) were used. Our findings show that GDP has a certain degree of effect on air transport. They also indicate that the unidirectional or bidirectional causal relationships running from GDP to air transport and air transport to GDP vary by the income level of countries.
\end{abstract}

Keywords: air transport, economic growth, panel causality, income level

JEL classification: L93, O11, C23, D63

\section{Introduction}

The close relationship between the demand for air transport and the country/ individual income is often underscored. Presumably, with the increase in income, individuals allocate more budget to traveling, and countries increase their infrastructure investments for air transport as well. Thus, a positive relationship is expected between the level of income of the country/individual and the demand for air transport. Therefore, in recent years there have been several studies on the relationship between air transport and economic growth (Hakim \& Merkert, 2016; $\mathrm{Hu}$ et al., 2015; Beyzatlar, Karacal \& Yetkiner, 2014; Mehmood \& Shahid, 2014; Profillidis \& Botzoris, 2015). In these studies, the relationship was examined empirically on the basis of a particular country or group of countries, whereas the relationship between air transport and economic growth was not addressed on the 
basis of countries' income levels. As such, the current study focuses on whether there is a causal relationship between air transport and economic growth, based on the income level of the ten countries, and whether the income level is has an effect on this relationship.

Many studies in the research literature examine the factors that determine the nature of air transport. In these studies, an air transport model was created to model GDP change, and it was analyzed to see if the GDP/per capita income had any effect on the air transport. The studies on factors affecting demand in air transport clearly show that GDP has a significant influence on air transport demand (Hutchinson, 1993; Alperovich \& Machnes, 1994; Aderamo, 2010). Additionally, some studies found a high correlation between the variables of air transport and economic determinants (Ba-Fail, Abed \& Jasimuddin, 2000; Baikgaki \& Daw, 2013).

The results of the above-mentioned studies show that GDP is an important determinant of air transport, but so far, very few studies have investigated the exact nature of the causality between GDP and air transport. Table 1 shows the studies on the causal relationship between air transport and economic growth. As seen in Table 1, there is an uncertainty about the direction of the relationship between GDP and air transport. The determination of this relationship is crucial in making infrastructure investments for air transport or prioritizing these investments. In addition, the determination of the relationship between GDP and air transport based on countries' income levels may be a guide for developing air transport policies in lower-middle-income and low-income countries.

This study is aimed to expand and strengthen the previous studies on the relationship between air transport and economic growth. Unlike previous studies, this study examined the causal relationship between air transport and economic growth based on the income level of countries. Another contribution of this study to the literature is its method of classifying countries into four different subcategories according to income level in order to solve the problem of "lumping-together" in the panel data analysis. Therefore, this study extends the empirical literature on the causal relationship between low-income, low-middle-income, high-middle-income, and high--income countries, air transport, and economic growth.

The purpose of this study is to examine the causal relationship between air transport and economic growth in 70 countries for the period of 1990-2016, by using the panel causality analysis of Kónya (2006) panel Granger causality analysis and Emirmahmutoğlu \& Köse (2011) panel causality analysis. The rest of this article is organized as follows: in the following section, the method and data used in the study will be described. In the third section, the empirical findings obtained 
Kasım Kiracı, Mahmut Bakır

from the analysis will be presented. In the fourth section, the findings will be discussed followed by a conclusion.

Table 1. Summary of empirical studies on air transport - economic growth nexus.

\begin{tabular}{|c|c|c|c|c|}
\hline Authors & Period & Country & Methodology & $\begin{array}{l}\text { S-L Run/ } \\
\text { Causality }\end{array}$ \\
\hline $\begin{array}{l}\text { Baker, Merkert \& } \\
\text { Kamruzzaman }(2015)\end{array}$ & $\begin{array}{l}1985- \\
2011 \\
\end{array}$ & $\begin{array}{l}\text { Australia (88 re- } \\
\text { gional airports) }\end{array}$ & $\begin{array}{l}\text { Cointegration and } \\
\text { Granger causality }\end{array}$ & $\mathrm{GDP} \rightarrow \mathrm{AT}$ \\
\hline $\begin{array}{l}\text { Profillidis \& Botzoris } \\
(2015)\end{array}$ & $\begin{array}{l}1980- \\
2013 \\
\end{array}$ & $\begin{array}{l}\text { World (8 geo- } \\
\text { graphical area) }\end{array}$ & $\begin{array}{l}\text { Econometric } \\
\text { models }\end{array}$ & $\mathrm{AT} \rightarrow \mathrm{GDP}$ \\
\hline $\begin{array}{l}\text { Mehmood \& Shahid } \\
\text { (2014) }\end{array}$ & $\begin{array}{l}1970- \\
2012\end{array}$ & Czech Republic & $\begin{array}{l}\text { Cointegration, } \\
\text { FMOLS, DOLS } \\
\text { and CCR }\end{array}$ & $\mathrm{GDP} \rightarrow \mathrm{AT}$ \\
\hline $\begin{array}{l}\text { Beyzatlar, Karacal \& } \\
\text { Yetkiner (2014) }\end{array}$ & $\begin{array}{l}1970- \\
2008\end{array}$ & 15-EU countries & Granger causality & $\mathrm{GDP} \rightarrow \mathrm{AT}$ \\
\hline Hu et al. (2015) & $\begin{array}{l}2006- \\
2012(Q)\end{array}$ & China & $\begin{array}{l}\text { Heterogeneous } \\
\text { panels-Granger } \\
\text { causality }\end{array}$ & $\mathrm{AT} \rightarrow \mathrm{GDP}$ \\
\hline Chi \& Beak (2013) & $\begin{array}{l}1996- \\
2011(\mathrm{~m}) \\
\end{array}$ & United States & $\begin{array}{l}\text { Cointegration } \\
\text { ARDL and ECM }\end{array}$ & $\begin{array}{l}\text { Short-run } \\
\text { causality }\end{array}$ \\
\hline $\begin{array}{lll}\text { Hakim } & \& & \text { Merkert } \\
(2016) & & \\
\end{array}$ & $\begin{array}{l}1973- \\
2014 \\
\end{array}$ & $\begin{array}{l}8 \text { South Asian } \\
\text { countries }\end{array}$ & $\begin{array}{l}\text { Cointegration and } \\
\text { Granger causality }\end{array}$ & $\mathrm{GDP} \rightarrow \mathrm{AT}$ \\
\hline Brida et al. (2014) & $\begin{array}{l}1995- \\
2013\end{array}$ & Mexico & $\begin{array}{l}\text { Cointegration and } \\
\text { Granger causality }\end{array}$ & $\begin{array}{c}\text { GDP } \leftrightarrow \text { AT } \\
\text { Long-run } \\
\text { causality }\end{array}$ \\
\hline $\begin{array}{l}\text { Nisansala \& Mudun- } \\
\text { kotuwa (2015) }\end{array}$ & $\begin{array}{l}1976- \\
2012\end{array}$ & Sri Lanka & $\begin{array}{l}\text { Cointegration, } \\
\text { Granger causality }\end{array}$ & $\begin{array}{c}\text { GDP } \leftrightarrow \text { AT } \\
\text { Long-run } \\
\text { causality } \\
\end{array}$ \\
\hline $\begin{array}{l}\text { Bal, Manga \& Gümüş } \\
\text { Akar (2017) }\end{array}$ & $\begin{array}{l}1967- \\
2015\end{array}$ & Turkey & Granger causality & $\mathrm{AT} \rightarrow \mathrm{GDP}$ \\
\hline $\begin{array}{l}\text { Anfofum, Saheed \& } \\
\text { Iluno (2015) }\end{array}$ & $\begin{array}{l}1980- \\
2012\end{array}$ & Nigeria & $\begin{array}{l}\text { Cointegration, } \\
\text { Granger causality }\end{array}$ & $\begin{array}{l}\text { GDP } \rightarrow \text { AT } \\
\text { Long-run } \\
\text { causality }\end{array}$ \\
\hline $\begin{array}{lll}\begin{array}{l}\text { Mukkala } \\
(2013)\end{array} & \text { Tervo } \\
\end{array}$ & $\begin{array}{l}1991- \\
2010 \\
\end{array}$ & $\begin{array}{l}13 \text { countries (in } \\
\text { Europa) }\end{array}$ & $\begin{array}{l}\text { Cointegration, } \\
\text { Granger causality }\end{array}$ & $\mathrm{AT} \rightarrow \mathrm{GDP}$ \\
\hline $\begin{array}{l}\text { Marazzo, Scherre \& } \\
\text { Fernandes }(2010)\end{array}$ & $\begin{array}{l}1996- \\
2006\end{array}$ & Brazil & $\begin{array}{l}\text { Cointegration, } \\
\text { Granger causality }\end{array}$ & $\begin{array}{l}\text { GDP } \rightarrow \text { AT } \\
\text { Long-run } \\
\text { causality }\end{array}$ \\
\hline $\begin{array}{l}\text { Mehmood \& Shahid } \\
(2014)\end{array}$ & $\begin{array}{l}1970- \\
2012 \\
\end{array}$ & Romania & Granger causality & $\mathrm{AT} \rightarrow \mathrm{GDP}$ \\
\hline $\begin{array}{l}\text { Fernandes \& Pacheco } \\
(2010)\end{array}$ & $\begin{array}{l}1966- \\
2006\end{array}$ & Brazil & Granger causality & $\begin{array}{l}\text { Long-run } \\
\text { causality }\end{array}$ \\
\hline
\end{tabular}


Note: GDP $\rightarrow$ AT means that the causality runs from economic growth to air transport.

AT $\rightarrow$ GDP means that the causality runs from air transport to economic growth. GDP $\leftrightarrow$ AT means that bidirectional causality exists between air transport and economic growth. AT (air transport), GDP= gross domestic product, VAR=vector autoregressive model, FMOLS $=$ fully modified ordinary least square, DOLS $=$ dynamic ordinary least square, $\mathrm{CCR}=$ conical cointegration regression $\mathrm{ECM}=$ error correction model and ARDL=autoregressive distributed lag, S-L Run = short or long-run causality.

\section{Data and Method}

Two key variables (air transport (AT) and GDP per capita in \$US) were used in this study to examine the causal relationship between air transport and economic growth. In the study of 1990-2016 period, a total of 70 countries were analyzed, including 20 high income, 20 upper middle income, 20 lower middle income and 10 low income. These countries are shown in Appendix-1. All data were obtained from the World bank database (The World Bank, 2018). Descriptive statistics of the AT and GDP variables for the four groups of countries classified by income level are shown in Table 2.

Two different analyses were used to examine the causal relationship between air transport and economic growth on the basis of income level of countries. The first of these is the bootstrap panel Granger causality analysis based on the heterogeneity hypothesis developed by Kónya (2006). The second is the panel causality test developed by Emirmahmutoğlu \& Köse (2011) and used for heterogeneous mixed models.

Table 2. Descriptive statistics of included variables

\begin{tabular}{|l|l|l|l|l|l|}
\hline & Variables & Mean & Maximum & Minimum & Std. Dev. \\
\hline \multirow{2}{*}{ High income } & GDP & 44298.67 & 111968.30 & 20469.26 & 15503.04 \\
\cline { 2 - 6 } & AT & 61455129 & 823000000 & 405700 & 139000000 \\
\hline $\begin{array}{l}\text { Upper middle } \\
\text { income }\end{array}$ & GDP & 6563.96 & 14071.17 & 730.77 & 2354.05 \\
\cline { 2 - 6 } $\begin{array}{l}\text { Lower middle } \\
\text { income }\end{array}$ & AT & 19768458 & 488000000 & 62798 & 47996885 \\
\hline \multirow{2}{*}{ low income } & GDP & 1584.66 & 3786.53 & 193.24 & 853.31 \\
\cline { 2 - 6 } & AT & 4476181 & 120000000 & 8000 & 11454513 \\
\cline { 2 - 6 } & GDP & 540.08 & 1342.54 & 161.83 & 263.63 \\
\hline
\end{tabular}


Note: AT is air passengers carried include both domestic and international aircraft passengers of air carriers registered in the country and GDP per capita is gross domestic product divided by midyear population. Data are in constant 2010 U.S. \$.

\section{Empirical Findings}

\section{Cross-sectional dependence}

The cross-sectional dependence test was performed before the causality analysis was conducted. Cross-sectional dependence is related to whether the shock panel formed in one of the series affects all the units in the panel data. In this study, Breusch \& Pagan (1980), Pesaran (2004), and Pesaran et al. (2008) cross-sectional dependence tests were used. Table 3 shows the cross-sectional dependence test results. The results of the analysis show that the $H_{0}$ hypothesis is rejected for all four income levels. Thus, cross-sectional dependence is achieved in the series.

Table 3. Cross-sectional dependence test results

\begin{tabular}{|l|l|r|r|}
\hline Country Group & Test & \multicolumn{1}{c|}{ GDP } & \multicolumn{1}{c|}{ ATP } \\
\hline \multirow{4}{*}{ High income } & CDlm (Breusch \& Pagan, 1980) & $417.780^{*}$ & $444.771^{*}$ \\
\cline { 2 - 4 } & CDlm (Pesaran, 2004) & $11.685^{*}$ & $13.069 *$ \\
\cline { 2 - 4 } & LMadj (Pesaran, Ullah \& Yamagata, 2008) & $30.009 *$ & $33.068^{*}$ \\
\hline \multirow{5}{*}{ Upper middle income } & CDlm (Breusch \& Pagan, 1980) & $274.317^{*}$ & $336.037 *$ \\
\cline { 2 - 4 } & CDlm (Pesaran, 2004) & $4.325^{*}$ & $7.492^{*}$ \\
\cline { 2 - 4 } & LMadj (Pesaran, Ullah \& Yamagata, 2008) & $27.941 *$ & $22.802^{*}$ \\
\hline \multirow{3}{*}{ low income } & CDlm (Breusch \& Pagan, 1980) & $274.760^{*}$ & $622.986^{*}$ \\
\cline { 2 - 4 } & CDlm (Pesaran, 2004) & $4.348^{*}$ & $22.212^{*}$ \\
\cline { 2 - 4 } & LMadj (Pesaran, Ullah \& Yamagata, 2008) & $34.326^{*}$ & $31.845^{*}$ \\
\hline & CDlm (Breusch \& Pagan, 1980) & $73.061 *$ & $117.372^{*}$ \\
\cline { 2 - 4 } & CDlm (Pesaran, 2004) & $2.958^{*}$ & $7.629 *$ \\
\cline { 2 - 4 } & LMadj (Pesaran, Ullah \& Yamagata, 2008) & $49.324 *$ & $21.951^{*}$ \\
\hline
\end{tabular}

Note: * indicates that the null hypothesis $\left(H_{0}\right)$ was rejected at the $1 \%$ level of significance.

\section{Kónya (2006) Panel Causality Test}

In the panel causality method developed by Kónya (2006), the seemingly unrelated regressions (SUR) estimator is used instead of the least squares (OLS). In addition, in the Wald test performed, bootstrap test statistics are used instead of asymptotic critical test statistics. In this way, cross-sectional dependency and heterogeneity are 
taken into account, and preliminary tests on the series such as stability and cointegration are not required. In this method, a common hypothesis is not required for all members of the panel because the direction of causality is analyzed based on country-specific bootstrap critical values in the Wald test (K1lıç, Buğan \& Özbezek, 2016; Kar, Nazlığlu \& Ağır, 2011). The Kónya (2006) panel causality approach describes a system that contains two sets of equations. The bootstrap based panel causality method can be expressed by the following equation system:

$$
\begin{aligned}
& y_{1 t}=\alpha_{1,1}+\sum_{i=1}^{l y_{1}} \beta_{1,1, i} y_{1, t-i}+\sum_{i=1}^{l x_{1}} \delta_{1,1, i} x_{k, 1, t-i}+\varepsilon_{1,1, t} \\
& y_{2 t}=\alpha_{1,2}+\sum_{i=1}^{l y_{1}} \beta_{1,2, i} y_{2, t-i}+\sum_{i=1}^{l x_{1}} \delta_{1,2, i} x_{k, 2, t-i}+\varepsilon_{1,2, t}(1) \\
& y_{N, t}=\alpha_{1, N}+\sum_{i=1}^{l y_{1}} \beta_{1, N, i} y_{N, t-i}+\sum_{i=1}^{l x_{1}} \delta_{1, N, i} x_{k, N, t-i}+\varepsilon_{1, N, t}
\end{aligned}
$$

and

$$
\begin{gathered}
x_{k, 1, t}=\alpha_{2,1}+\sum_{i=1}^{l y_{2}} \beta_{2,2, i} y_{2, t-i}+\sum_{i=1}^{l x_{2}} \delta_{2,2, i} x_{k, 2, t-i}+\varepsilon_{2,1, t} \\
x_{k, 2, t}=\alpha_{2,2}+\sum_{i=1}^{l y_{2}} \beta_{2,2, i} y_{2, t-i}+\sum_{i=1}^{l x_{2}} \delta_{2,2, i} x_{k, 2, t-i}+\varepsilon_{2,2, t} \\
x_{k, N, t}=\alpha_{2, N}+\sum_{i=1}^{l y_{2}} \beta_{2, N, i} y_{N, t-i}+\sum_{i=1}^{l x_{2}} \delta_{2, N, i} x_{k, N, t-i}+\varepsilon_{2, N, t}
\end{gathered}
$$

In this equation, $y$ is the air transport (AT), and $x$ is the GDP per capita (GDP). Further, $N$ is the number of units (countries) in the panel, $(j=1, \ldots, N), t$ is the time period, and $(t=1, \ldots, T), l$ is the delay number. $l y_{1}$ and $l x_{1}$ are the maximum delay lengths of the variables in the first equation set, $l y_{2}$ and $l x_{2}$ are the maximum delay lengths of the variables in the second equation system. As a result of the application, for a unit (country) if all the $(i), \delta_{1, i}$ coefficients are not equal to zero and $\beta_{2, i}$ coefficients are all equal to zero, then there is a unidirectional causal relationship from variable $x$ to variable $y$; there is a unidirectional causal relationship from variable $y$ to variable $x$ if $\beta_{2, i}$ coefficients are all not equal to zero and $\delta_{1, i}$ coefficients are all equal to zero. In addition, if all the $\delta_{1, i}$ and $\beta_{2, i}$ coefficients are not equal to zero, then there is bidirectional causality between the 
Kasım Kirac1, Mahmut Bakır

variables. If $\delta_{1, i}$ and $\beta_{2, i}$ coefficients are all equal to zero, it is concluded that there is no causal relationship between the variables. The bootstrap panel causality test results obtained from the analysis are shown in the following tables.

Table 4. Kónya (2006) causality test results for high-income countries

\begin{tabular}{|c|c|c|c|c|c|c|c|c|}
\hline \multirow{3}{*}{ Country } & \multicolumn{4}{|c|}{ GDP $\rightarrow$ AT } & \multicolumn{4}{|c|}{ AT $\rightarrow$ GDP } \\
\hline & \multirow{2}{*}{$w_{i}$} & \multicolumn{3}{|c|}{ Bootstrap Critical Values } & \multirow[t]{2}{*}{$w_{i}$} & \multicolumn{3}{|c|}{ Bootstrap Critical Values } \\
\hline & & $1 \%$ & $5 \%$ & $10 \%$ & & $1 \%$ & $5 \%$ & $10 \%$ \\
\hline Australia & 16.589 & 99.193 & 56.866 & 45.078 & 0.291 & 66.349 & 39.636 & 27.074 \\
\hline Austria & 15.151 & 173.064 & 127.554 & 102.539 & 1.028 & 184.002 & 108.717 & 83.170 \\
\hline Belgium & 0.002 & 12.753 & 8.582 & 6.487 & 0.409 & 43.987 & 25.370 & 17.831 \\
\hline Canada & 19.197 & 138.947 & 88.207 & 72.982 & 3.530 & 184.371 & 113.995 & 76.683 \\
\hline Finland & 1.010 & 45.306 & 28.291 & 22.209 & 1.210 & 144.007 & 83.571 & 66.840 \\
\hline France & 30.474 & 243.730 & 171.175 & 139.447 & 0.131 & 586.777 & 291.069 & 224.068 \\
\hline Germany & 0.048 & 162.859 & 93.155 & 72.316 & 53.763 & 340.450 & 224.616 & 175.333 \\
\hline Iceland & $10.923 *$ & 10.041 & 5.426 & 3.709 & 19.234 & 125.606 & 58.739 & 48.858 \\
\hline Ireland & 51.848 & 101.492 & 65.726 & 55.813 & 4.221 & 38.638 & 27.800 & 22.395 \\
\hline Israel & 65.843 & 573.504 & 315.597 & 232.315 & 3.014 & 683.525 & 359.168 & 259.927 \\
\hline Italy & 47.470 & 320.088 & 236.739 & 180.225 & 22.148 & 640.617 & 306.166 & 216.966 \\
\hline Japan & 2.041 & 105.896 & 52.187 & 37.427 & 0.310 & 369.387 & 238.932 & 186.025 \\
\hline Luxembourg & 0.814 & 34.879 & 22.986 & 18.809 & 8.438 & 204.584 & 102.366 & 71.492 \\
\hline Netherlands & 0.005 & 83.563 & 55.457 & 44.938 & 57.891 & 356.576 & 226.937 & 180.980 \\
\hline New Zealand & 6.173 & 373.519 & 213.185 & 158.173 & 25.094 & 281.306 & 173.008 & 135.749 \\
\hline Singapore & 33.027 & 505.349 & 309.788 & 257.755 & 21.770 & 343.225 & 216.447 & 166.308 \\
\hline Switzerland & 8.163 & 152.474 & 87.422 & 65.601 & 2.338 & 78.240 & 54.053 & 40.649 \\
\hline $\begin{array}{l}\text { United Arab } \\
\text { Emirates }\end{array}$ & $192.9 * * *$ & 304.955 & 188.070 & 137.244 & 5.047 & 48.639 & 29.215 & 21.041 \\
\hline $\begin{array}{l}\text { United } \\
\text { Kingdom }\end{array}$ & 0.325 & 61.636 & 41.502 & 35.355 & 0.752 & 110.341 & 67.715 & 51.411 \\
\hline United States & 28.813 & 438.689 & 293.553 & 236.682 & 6.999 & 367.445 & 225.502 & 181.234 \\
\hline
\end{tabular}

Note: GDP $\rightarrow$ AT means that the causality runs from GDP to air transport. AT $\rightarrow$ GDP means that the causality runs from air transport to GDP. GDP $\leftrightarrow$ AT means that bidirectional causality exists between air transport and GDP *,** and *** indicate that the test statistic is significant at the $1 \%, 5 \%$ and $10 \%$ significance levels, respectively. The optimal lag length was decided according to the Akaike information criterion. The bootstrap number is 1000 . The maximum delay length is 3 . 
Causal Relationship Between Air Transport and Economic Growth: Evidence from Panel

In Table 4, the results of causality analysis for high-income countries are displayed. Accordingly, Iceland and United Arab Emirates have a causal relationship running from GDP to air transport. In contrast, none of the high-income countries has a causal relationship with direction from air transport to GDP.

Table 5. Kónya (2006) causality test results for upper-middle-income countries

\begin{tabular}{|l|l|l|l|l|l|l|l|l|}
\hline \multirow{2}{*}{ Country } & \multicolumn{4}{|c|}{ GDP $\rightarrow$ ATP } & \multicolumn{4}{c|}{ ATP $\rightarrow$ GDP } \\
\cline { 2 - 9 } & \multirow{2}{*}{$\boldsymbol{w}_{\boldsymbol{i}}$} & \multicolumn{1}{|c|}{ Bootstrap Critical Values } & \multicolumn{1}{|c|}{$\boldsymbol{w}_{\boldsymbol{i}}$} & \multicolumn{2}{c|}{ Bootstrap Critical Values } \\
\cline { 2 - 9 } & & $\mathbf{1 \%}$ & $\mathbf{5 \%}$ & $\mathbf{1 0 \%}$ & & \multicolumn{1}{|c}{$\mathbf{5 \%}$} & $\mathbf{5 \%}$ & $\mathbf{1 0 \%}$ \\
\hline Argentina & 8.544 & 210.395 & 130.848 & 100.199 & 1.342 & 140.536 & 80.022 & 59.955 \\
\hline Botswana & 2.018 & 58.901 & 29.311 & 22.838 & 31.967 & 143.693 & 77.213 & 51.462 \\
\hline Brazil & $304.4 * *$ & 312.304 & 173.772 & 145.288 & 20.630 & 550.996 & 310.436 & 239.563 \\
\hline Bulgaria & $7.93 * * *$ & 15.699 & 8.262 & 5.678 & $151.98 *$ & 110.492 & 63.005 & 43.054 \\
\hline China & 4.418 & 314.794 & 165.152 & 132.641 & 44.204 & 137.261 & 71.625 & 49.286 \\
\hline Colombia & 38.037 & 253.407 & 166.549 & 139.682 & 0.094 & 248.425 & 168.679 & 126.652 \\
\hline Costa Rica & 7.150 & 79.568 & 49.237 & 40.113 & 6.060 & 110.480 & 63.727 & 44.663 \\
\hline Ecuador & 40.900 & 393.226 & 246.720 & 182.109 & 0.492 & 478.206 & 284.175 & 210.920 \\
\hline Lebanon & 44.445 & 203.516 & 123.309 & 102.244 & 4.591 & 15.392 & 9.806 & 6.288 \\
\hline Malaysia & 13.951 & 175.908 & 115.985 & 87.530 & 24.003 & 101.889 & 60.438 & 51.771 \\
\hline Mauritius & 23.595 & 227.740 & 139.738 & 110.551 & 0.967 & 78.428 & 37.442 & 23.528 \\
\hline Mexico & 0.037 & 330.964 & 195.587 & 143.288 & 3.200 & 101.946 & 64.225 & 52.881 \\
\hline Panama & 99.749 & 253.088 & 181.440 & 140.748 & 4.131 & 76.048 & 43.106 & 29.378 \\
\hline Peru & 12.991 & 218.238 & 142.811 & 118.924 & 9.695 & 181.221 & 103.897 & 79.249 \\
\hline Romania & 25.541 & 202.509 & 120.920 & 101.912 & 5.525 & 624.361 & 317.424 & 251.516 \\
\hline $\begin{array}{l}\text { Russian } \\
\text { Federation }\end{array}$ & 11.274 & 53.861 & 34.802 & 27.524 & $103.65 *$ & 87.250 & 33.834 & 22.924 \\
\hline South Africa & 0.618 & 269.442 & 162.431 & 121.909 & 16.278 & 335.695 & 214.692 & 177.170 \\
\hline Suriname & 0.566 & 34.239 & 17.038 & 13.114 & 24.756 & 102.346 & 58.915 & 43.741 \\
\hline Thailand & 1.869 & 155.568 & 82.470 & 64.331 & 3.821 & 58.238 & 35.417 & 29.346 \\
\hline Turkey & 29.504 & 222.929 & 136.595 & 105.744 & 11.161 & 173.789 & 117.922 & 92.039 \\
\hline
\end{tabular}

Note: GDP $\rightarrow$ AT means that the causality runs from GDP to air transport. AT $\rightarrow$ GDP means that the causality runs from air transport to GDP. GDP $\leftrightarrow$ AT means that bidirectional causality exists between air transport and GDP $* * *$ and $* * *$ indicate that the test statistic is significant at the $1 \%, 5 \%$ and $10 \%$ significance levels, respectively. The optimal lag length was decided according to the Akaike information criterion. The bootstrap number is 1000 . The maximum delay length is 3 . 
Kasım Kiracı, Mahmut Bakır

In Table 5, the causality analysis results for the upper-middle-income countries are shown. The findings of the analysis show that there is a causal relationship that runs from GDP to air transport in Brazil. In Bulgaria, there is a bidirectional causal relationship running from GDP to air transport as well as from air transport to GDP. In the Russian Federation, the relationship indicates a unidirectional causality towards air transport GDP.

Table 6. Kónya (2006) causality test results for lower-middle-income countries

\begin{tabular}{|c|c|c|c|c|c|c|c|c|}
\hline \multirow{3}{*}{ Country } & \multicolumn{4}{|c|}{ GDP $\rightarrow$ ATP } & \multicolumn{4}{|c|}{$\mathbf{A T P} \rightarrow$ GDP } \\
\hline & \multirow{2}{*}{$w_{i}$} & \multicolumn{3}{|c|}{ Bootstrap Critical Values } & \multirow{2}{*}{$w_{i}$} & \multicolumn{3}{|c|}{ Bootstrap Critical Values } \\
\hline & & $1 \%$ & $5 \%$ & $10 \%$ & & $1 \%$ & $5 \%$ & $10 \%$ \\
\hline Angola & 27.391 & 63.369 & 45.510 & 37.543 & 0.079 & 27.424 & 12.220 & 8.175 \\
\hline Bangladesh & 22.735 & 96.386 & 56.362 & 45.120 & $176.6 * * *$ & 417.163 & 230.096 & 171.002 \\
\hline Bhutan & 33.826 & 120.219 & 79.331 & 63.662 & 12.748 & 52.137 & 22.289 & 15.305 \\
\hline Bolivia & $38.7 * * *$ & 76.993 & 45.389 & 33.956 & 0.067 & 100.159 & 45.782 & 30.203 \\
\hline Cabo Verde & 5.389 & 87.976 & 49.176 & 31.813 & 24.925 & 100.880 & 59.211 & 48.258 \\
\hline Cameroon & 0.295 & 21.024 & 12.224 & 7.507 & $70.5^{* * *}$ & 139.534 & 71.925 & 48.787 \\
\hline Egypt & $408.6^{* *}$ & 424.555 & 317.052 & 272.227 & 7.287 & 184.610 & 76.234 & 52.076 \\
\hline India & 8.026 & 126.817 & 82.679 & 69.078 & 10.982 & 42.161 & 23.725 & 14.464 \\
\hline Jordan & 15.044 & 314.340 & 218.830 & 182.142 & 4.842 & 98.599 & 53.806 & 37.883 \\
\hline Kenya & 1.013 & 442.326 & 232.794 & 183.948 & 152.791 & 314.559 & 195.406 & 153.262 \\
\hline Lao PDR & 29.364 & 115.257 & 82.398 & 69.432 & 38.877 & 205.496 & 109.327 & 85.109 \\
\hline Mauritania & 16.722 & 93.931 & 41.523 & 27.910 & $9.392 * * *$ & 35.750 & 12.993 & 8.290 \\
\hline Morocco & 80.353 & 352.358 & 247.448 & 197.436 & $83.95 * *$ & 181.549 & 78.999 & 55.986 \\
\hline Myanmar & 30.715 & 146.041 & 88.442 & 73.134 & 35.358 & 133.254 & 57.250 & 38.429 \\
\hline Nigeria & 42.813 & 321.322 & 208.024 & 179.415 & 0.082 & 61.670 & 36.696 & 26.426 \\
\hline Pakistan & 2.843 & 157.225 & 76.452 & 61.190 & 1.007 & 88.291 & 51.153 & 37.671 \\
\hline Philippines & $121.96 * *$ & 151.937 & 106.132 & 89.406 & 0.098 & 17.162 & 9.668 & 6.757 \\
\hline Sudan & 4.982 & 87.253 & 40.949 & 29.624 & $104.6^{* *}$ & 193.717 & 76.618 & 48.593 \\
\hline Vanuatu & 32.550 & 174.563 & 99.814 & 81.098 & 10.266 & 26.838 & 15.694 & 11.652 \\
\hline Vietnam & 1.888 & 33.559 & 17.479 & 12.898 & 0.254 & 88.173 & 57.884 & 45.053 \\
\hline
\end{tabular}

Note: GDP $\rightarrow$ AT means that the causality runs from GDP to air transport. AT $\rightarrow$ GDP means that the causality runs from air transport to GDP. GDP $\leftrightarrow$ AT means that bidirectional causality exists between air transport and GDP *,** and *** indicate that the test statistic is significant at the $1 \%, 5 \%$ and $10 \%$ significance levels, respectively. The optimal lag length was decided according to the Akaike information criterion. The bootstrap number is 1000 . The maximum delay length is 3 . 
In Table 6, the causality analysis results for the lower-middle-income countries are shown. Accordingly, there is a unidirectional causal relationship that runs from GDP to air transport in three countries. These countries are Bolivia, Egypt and Philippines. In addition, the results of the analysis show that in five countries there is a unidirectional causal relationship running from air transport to GDP. These countries are Bangladesh, Cameroon, Mauritania, Morocco and Sudan.

Table 7. Kónya (2006) causality test results for low-income countries

\begin{tabular}{|c|c|c|c|c|c|c|c|c|}
\hline \multirow{3}{*}{ Country } & \multicolumn{4}{|c|}{ GDP $\rightarrow$ ATP } & \multicolumn{4}{|c|}{$\mathbf{A T P} \rightarrow$ GDP } \\
\hline & \multirow{2}{*}{$w_{i}$} & \multicolumn{3}{|c|}{ Bootstrap Critical Values } & \multirow{2}{*}{$w_{i}$} & \multicolumn{3}{|c|}{ Bootstrap Critical Values } \\
\hline & & $1 \%$ & $5 \%$ & $10 \%$ & & $1 \%$ & $5 \%$ & $10 \%$ \\
\hline Burkina Faso & 0.307 & 7.225 & 4.573 & 3.431 & 1.645 & 4.604 & 2.584 & 1.883 \\
\hline Ethiopia & 10.862 & 52.194 & 40.125 & 34.509 & 12.347 & 93.014 & 68.523 & 58.732 \\
\hline Madagascar & $35.804^{*}$ & 12.271 & 6.356 & 4.054 & 0.219 & 27.576 & 15.948 & 12.036 \\
\hline Malawi & $16.01 * * *$ & 22.980 & 16.682 & 14.658 & 0.657 & 13.342 & 9.010 & 7.323 \\
\hline Mozambique & 14.843 & 38.882 & 30.057 & 26.457 & $3.76 * *$ & 4.421 & 2.341 & 1.596 \\
\hline Nepal & 0.014 & 6.043 & 4.059 & 2.878 & 0.035 & 5.964 & 3.330 & 2.389 \\
\hline Senegal & 1.958 & 17.865 & 10.851 & 8.464 & 0.541 & 8.452 & 4.932 & 3.358 \\
\hline Tanzania & 8.615 & 27.883 & 19.114 & 17.043 & $2.62 * * *$ & 5.908 & 3.280 & 2.099 \\
\hline Uganda & 3.528 & 10.398 & 6.303 & 3.968 & 2.323 & 9.634 & 5.084 & 3.052 \\
\hline Zimbabwe & 0.214 & 43.795 & 30.013 & 24.204 & $36.5 * * *$ & 64.281 & 37.725 & 30.847 \\
\hline
\end{tabular}

Note: GDP $\rightarrow$ AT means that the causality runs from GDP to air transport. AT $\rightarrow$ GDP means that the causality runs from air transport to GDP. GDP $\leftrightarrow$ AT means that bidirectional causality exists between air transport and GDP *,** and *** indicate that the test statistic is significant at the $1 \%, 5 \%$ and $10 \%$ significance levels, respectively. The optimal lag length was decided according to the Akaike information criterion. The bootstrap number is 1000 . The maximum delay length is 3 .

Table 7 shows the causality analysis results for low-income countries. The results demonstrate that there is a causal relationship from GDP to air transport for Madagascar and Malawi. In addition, there are three countries where there is a causal relationship running from air transport to GDP. These countries are Mozambique, Tanzania and Zimbabwe.

\section{Emirmahmutoğlu \& Köse (2011) Panel Causality Test}

The panel causality test, a panel data version of the causality test developed by Toda \& Yamamota (1995), was used in the study. Developed by Emirmahmutoğlu \& Köse (2011), this test is based on meta analysis in mixed heterogeneous panes. In the meta analysis developed by Fisher (1932), $\mathrm{N}$ units are tested and the 
significance levels (probability values) of this test are used (Zeren \& Ergün, 2013:p.233). In a later stage, a single panel statistic is created using these probability values of the units. The advantage of this test is that it reduces longterm information loss by modelling with the level values of series, that it allows delay length to vary for each series, and that it takes the cross-sectional dependency into account (Gözbaş1, 2015:p.277; Gümüş \& Koç, 2015:p.155; Büberkökü, 2016:p.189).

In this method, first, a standard Panel VAR estimate is made and the appropriate delay length (p) is determined. Then, for the appropriate delay length, the degree of integration of the variable with the highest degree of integration $\left(d_{\max }\right)$ is added. In the last stage, a Panel VAR model is estimated using the level values of the variables for the delay level $\left(p+d_{\max }\right)$ (Göçer, 2013:p.132; K1lıç, Buğan \& Özbezek, 2016:p.1139; Emirmahmutoğlu \& Köse, 2011:pp.871-872; Topall1, 2016:p.89). In the Emirmahmutoğlu \& Köse (2011) method, the following Panel VAR model is estimated for each cross-section.

$x_{i t}=\mu_{i}^{x}+\sum_{j=1}^{k_{i}+d \max _{i}} A_{11, i j} x_{i, t-j}+\sum_{j=1}^{k_{i}+d \max _{i}} A_{12, i j} y_{i, t-j}-u_{i, t}^{x}$

$y_{i t}=\mu_{i}^{x}+\sum_{j=1}^{k_{i}+d \max _{i}} A_{21, i j} x_{i, t-j}+\sum_{j=1}^{k_{i}+d \max _{i}} A_{22, i j} y_{i, t-j}-u_{i, t}^{x}$

In the analysis, the modified Wald test is performed for the predicted $k_{i}$ delay length. $H_{0}$ hypothesis is formed as "there is no causal relationship from $y$ to $x$ ". Panel Fisher test statistics used in the study are presented in the following tables according to the income level of the countries.

Table 8. Emirmahmutoğlu \& Köse (2011) causality test results for high-income countries

\begin{tabular}{|l|c|c|c|c|c|}
\hline \multirow{2}{*}{ Country } & & \multicolumn{2}{|c|}{ GDP $\rightarrow$ ATP } & \multicolumn{2}{c|}{ ATP $\rightarrow$ GDP } \\
\cline { 2 - 6 } & $\boldsymbol{k}_{\boldsymbol{i}}$ & $\boldsymbol{w}_{\boldsymbol{i}}$ & prob. & $\boldsymbol{w}_{\boldsymbol{i}}$ & prob. \\
\hline Australia & 3 & $19.407^{*}$ & 0.0000 & 2.700 & 0.4400 \\
\hline Austria & 3 & $20.289^{*}$ & 0.0000 & 0.400 & 0.9400 \\
\hline Belgium & 1 & 0.180 & 0.6710 & 0.011 & 0.9160 \\
\hline Canada & 3 & 1.353 & 0.7170 & 0.026 & 0.9990 \\
\hline Finland & 2 & 3.245 & 0.1970 & 1.271 & 0.5300 \\
\hline France & 1 & 0.190 & 0.6630 & 0.868 & 0.3520 \\
\hline
\end{tabular}


Causal Relationship Between Air Transport and Economic Growth: Evidence from Panel Data for High, Upper-Middle, Lower-Middle and Low-Income Countries

\begin{tabular}{|l|c|c|c|c|c|}
\hline Germany & 3 & 4.405 & 0.2210 & 0.455 & 0.9290 \\
\hline Iceland & 2 & $8.408^{* *}$ & 0.0150 & 1.159 & 0.5600 \\
\hline Ireland & 3 & 0.822 & 0.8440 & $9.564 * *$ & 0.0230 \\
\hline Israel & 1 & 0.030 & 0.8620 & 0.535 & 0.4640 \\
\hline Italy & 2 & $5.603 * * *$ & 0.0610 & $5.963 * * *$ & 0.0510 \\
\hline Japan & 2 & 4.243 & 0.1200 & 1.002 & 0.6060 \\
\hline Luxembourg & 1 & 0.107 & 0.7430 & 0.278 & 0.5980 \\
\hline Netherlands & 2 & $7.197 * *$ & 0.0270 & 1.814 & 0.4040 \\
\hline New Zealand & 2 & $4.633 * * *$ & 0.0990 & 0.044 & 0.9780 \\
\hline Singapore & 1 & 0.891 & 0.3450 & 1.689 & 0.1940 \\
\hline Switzerland & 2 & 3.177 & 0.2040 & 0.832 & 0.6600 \\
\hline United Arab Emirates & 1 & $6.458^{* *}$ & 0.0110 & 1.229 & 0.2680 \\
\hline United Kingdom & 3 & $6.616^{* * *}$ & 0.0850 & 0.054 & 0.9970 \\
\hline United States & 2 & 1.318 & 0.5170 & 1.657 & 0.4370 \\
\hline Panel Fisher & & $94.857 *$ & 0.0000 & 33.988 & 0.737 \\
\hline
\end{tabular}

Note: GDP $\rightarrow$ AT means that the causality runs from GDP to air transport. AT $\rightarrow$ GDP means that the causality runs from air transport to GDP. GDP $\leftrightarrow$ AT means that bidirectional causality exists between air transport and GDP *,** and *** indicate that the test statistic is significant at the $1 \%, 5 \%$ and $10 \%$ significance levels, respectively. The optimal lag length was decided according to the Akaike information criterion. The bootstrap number is 1000 . The maximum delay length is 3 .

In Table 8, causality analysis results for high-income countries are shown. Accordingly, there is a direct causal relationship between GDP and air transport in Australia, Austria, Iceland, Netherlands, New Zealand, United Arab Emirates and United Kingdom. In addition, in Ireland, there is a causal relationship from air transport to GDP. In Italy, there is bidirectional causality running from GDP to air transport as well as from GDP to air transport. The Fisher test statistic results show that high-income countries have a unidirectional causal relationship running from GDP to air transport.

Table 9. Emirmahmutoğlu \& Köse (2011) causality test results for upper-middleincome countries

\begin{tabular}{|l|c|c|c|c|c|}
\hline \multirow{2}{*}{ Country } & & \multicolumn{2}{|c|}{ GDP $\rightarrow$ ATP } & \multicolumn{2}{c|}{ ATP $\rightarrow$ GDP } \\
\cline { 2 - 6 } & $\boldsymbol{k}_{\boldsymbol{i}}$ & $\boldsymbol{w}_{\boldsymbol{i}}$ & prob. & $\boldsymbol{w}_{\boldsymbol{i}}$ & prob. \\
\hline Argentina & 2 & $5.312 * * *$ & 0.0700 & 3.471 & 0.1760 \\
\hline Botswana & 3 & 5.129 & 0.1630 & 5.864 & 0.1180 \\
\hline Brazil & 3 & $45.022 *$ & 0.0000 & $8.52 * *$ & 0.0360 \\
\hline
\end{tabular}


Kasım Kirac1, Mahmut Bakır

\begin{tabular}{|l|c|c|c|c|c|}
\hline Bulgaria & 2 & 0.101 & 0.9510 & 3.001 & 0.2230 \\
\hline China & 2 & 0.863 & 0.6500 & 2.669 & 0.2630 \\
\hline Colombia & 1 & 0.199 & 0.6560 & 1.148 & 0.2840 \\
\hline Costa Rica & 3 & $11.574 *$ & 0.0090 & 5.969 & 0.1130 \\
\hline Ecuador & 2 & $6.554 * *$ & 0.0380 & 2.417 & 0.2990 \\
\hline Lebanon & 3 & $11.035^{* *}$ & 0.0120 & 4.628 & 0.2010 \\
\hline Malaysia & 1 & 1.691 & 0.1930 & 0.255 & 0.6140 \\
\hline Mauritius & 1 & 2.033 & 0.1540 & 0.006 & 0.9400 \\
\hline Mexico & 1 & $3.588 * * *$ & 0.0580 & 0.684 & 0.4080 \\
\hline Panama & 3 & $10.993 * *$ & 0.0120 & 5.147 & 0.1610 \\
\hline Peru & 1 & 1.243 & 0.2650 & 0.098 & 0.7550 \\
\hline Romania & 3 & $10.844 * *$ & 0.0130 & $13.054 *$ & 0.0050 \\
\hline Russian Federation & 3 & 0.837 & 0.8410 & 3.329 & 0.3440 \\
\hline South Africa & 2 & 0.222 & 0.8950 & 0.631 & 0.7290 \\
\hline Suriname & 2 & 2.685 & 0.2610 & 1.806 & 0.4050 \\
\hline Thailand & 1 & 0.109 & 0.7410 & 0.920 & 0.3380 \\
\hline Turkey & 2 & 4.329 & 0.1150 & $4.770 * * *$ & 0.0920 \\
\hline Panel Fisher & & $118.467 *$ & 0.0000 & $61.95 * *$ & 0.0150 \\
\hline
\end{tabular}

Note: GDP $\rightarrow$ AT means that the causality runs from GDP to air transport. AT $\rightarrow$ GDP means that the causality runs from air transport to GDP. GDP $\leftrightarrow$ AT means that bidirectional causality exists between air transport and GDP *,** and *** indicate that the test statistic is significant at the $1 \%, 5 \%$ and $10 \%$ significance levels, respectively. The optimal lag length was decided according to the Akaike information criterion. The bootstrap number is 1000 . The maximum delay length is 3 .

Table 9 shows the causality analysis results for the upper-middle-income countries. The results indicate a unidirectional causal relationship running from GDP to air transport in Argentina, Costa Rica, Ecuador and Lebanon. Furthermore, in Brazil and Romania, there is a bidirectional causal relationship running from GDP to air transport as well as from GDP to air transport. In Turkey, there is a causality from air transport to GDP. For the upper-middle-income countries, the Fisher test statistics point to the presence of a causal relationship running from GDP to air transport at the $1 \%$ level of significance, and from air transport to GDP at the 5\% significance level.

Table 10. Emirmahmutoğlu \& Köse (2011) causality test results for lower-middleincome countries 
Causal Relationship Between Air Transport and Economic Growth: Evidence from Panel Data for High, Upper-Middle, Lower-Middle and Low-Income Countries

\begin{tabular}{|l|c|c|c|c|c|}
\hline \multirow{2}{*}{ Country } & & \multicolumn{2}{|c|}{ GDP $\rightarrow$ ATP } & \multicolumn{2}{c|}{ ATP $\rightarrow$ GDP } \\
\cline { 2 - 6 } & $\boldsymbol{k}_{\boldsymbol{i}}$ & $\boldsymbol{w}_{\boldsymbol{i}}$ & prob. & $\boldsymbol{w}_{\boldsymbol{i}}$ & prob. \\
\hline Angola & 1 & 1.344 & 0.2460 & 0.227 & 0.6340 \\
\hline Bangladesh & 1 & 0.021 & 0.8860 & $4.599 * *$ & 0.0320 \\
\hline Bhutan & 3 & 2.418 & 0.4900 & 0.747 & 0.8620 \\
\hline Bolivia & 1 & $2.778 * * *$ & 0.0960 & 0.107 & 0.7430 \\
\hline Cabo Verde & 2 & 1.548 & 0.4610 & 0.610 & 0.7370 \\
\hline Cameroon & 2 & $5.110^{* * *}$ & 0.0780 & $18.210 *$ & 0.0000 \\
\hline Egypt & 3 & 2.603 & 0.4570 & 1.593 & 0.6610 \\
\hline India & 3 & 3.652 & 0.3020 & 4.329 & 0.2280 \\
\hline Jordan & 3 & $30.329 *$ & 0.0000 & 1.471 & 0.6890 \\
\hline Kenya & 3 & $6.559 * * *$ & 0.0870 & $23.260 *$ & 0.0000 \\
\hline Lao PDR & 1 & 0.011 & 0.9150 & 1.171 & 0.2790 \\
\hline Mauritania & 1 & 0.179 & 0.6720 & 0.820 & 0.3650 \\
\hline Morocco & 2 & 3.392 & 0.1830 & $6.905 * *$ & 0.0320 \\
\hline Myanmar & 1 & 0.424 & 0.5150 & 0.005 & 0.9450 \\
\hline Nigeria & 2 & 3.572 & 0.1680 & 3.638 & 0.1620 \\
\hline Pakistan & 1 & 0.607 & 0.4360 & 0.117 & 0.7320 \\
\hline Philippines & 2 & 0.588 & 0.7450 & 3.320 & 0.1900 \\
\hline Sudan & 3 & 5.903 & 0.1160 & 0.646 & 0.8860 \\
\hline Vanuatu & 2 & $5.422 * * *$ & 0.0660 & 2.503 & 0.2860 \\
\hline Vietnam & 0.128 & 0.9380 & 0.489 & 0.7830 \\
\hline Panel Fisher & $73.328 *$ & 0.0010 & $74.922 *$ & 0.0010 \\
\hline
\end{tabular}

Note: GDP $\rightarrow$ AT means that the causality runs from GDP to air transport. AT $\rightarrow$ GDP means that the causality runs from air transport to GDP. GDP $\leftrightarrow$ AT means that bidirectional causality exists between air transport and GDP *,** and *** indicate that the test statistic is significant at the $1 \%, 5 \%$ and $10 \%$ significance levels, respectively. The optimal lag length was decided according to the Akaike information criterion. The bootstrap number is 1000 . The maximum delay length is 3 .

Table 10 shows the causality analysis results obtained for the lower-middle-income countries. Accordingly, there is a unidirectional causal relationship between GDP and air transport (running from GDP to AT) in Bolivia, Jordan and Vanuatu. In Bangladesh and Morocco, there is a causal relationship from air transport to GDP. Cameroon and Kenya are the countries that have bidirectional causal relationship from GDP to air transport as well as from GDP to air transport. The Fisher test statistics results show that the lower-middle-income countries have a causal 
relationship directed from GDP to air transport and from air transport to GDP at the $1 \%$ significance level.

Table 11. Emirmahmutoğlu \& Köse (2011) causality test results for low-income countries

\begin{tabular}{|l|c|c|c|c|c|}
\hline \multirow{2}{*}{ Country } & & \multicolumn{2}{|c|}{ GDP $\rightarrow$ ATP } & \multicolumn{2}{c|}{ ATP $\rightarrow$ GDP } \\
\cline { 2 - 6 } & $\boldsymbol{k}_{\boldsymbol{i}}$ & $\boldsymbol{w}_{\boldsymbol{i}}$ & prob. & $\boldsymbol{w}_{\boldsymbol{i}}$ & prob. \\
\hline Burkina Faso & 1 & 1.938 & 0.1640 & 0.364 & 0.5460 \\
\hline Ethiopia & 3 & $8.927 * *$ & 0.0300 & 1.224 & 0.7470 \\
\hline Madagascar & 1 & 2.558 & 0.1100 & 0.122 & 0.7270 \\
\hline Malawi & 3 & $8.488^{* *}$ & 0.0370 & 5.445 & 0.1420 \\
\hline Mozambique & 1 & 0.348 & 0.5550 & 0.552 & 0.4580 \\
\hline Nepal & 1 & 0.048 & 0.8270 & 0.227 & 0.6340 \\
\hline Senegal & 1 & 0.612 & 0.4340 & 0.006 & 0.9400 \\
\hline Tanzania & 3 & $21.357 *$ & 0.0000 & 5.630 & 0.1310 \\
\hline Uganda & 2 & 2.437 & 0.2960 & $5.589 * * *$ & 0.0610 \\
\hline Zimbabwe & 2 & 2.132 & 0.3440 & $9.372 *$ & 0.0090 \\
\hline Panel Fisher & & $48.082^{*}$ & 0.0000 & 27.958 & 0.1100 \\
\hline
\end{tabular}

Note: GDP $\rightarrow$ AT means that the causality runs from GDP to air transport. AT $\rightarrow$ GDP means that the causality runs from air transport to GDP. GDP $\leftrightarrow$ AT means that bidirectional causality exists between air transport and GDP *,** and *** indicate that the test statistic is significant at the $1 \%, 5 \%$ and $10 \%$ significance levels, respectively. The optimal lag length was decided according to the Akaike information criterion. The bootstrap number is 1000 . The maximum delay length is 3 .

Table 11 shows the causality analysis results for the low-income countries. The results of the analysis show that there is a causal relationship between GDP and air transport (from GDP to AT) in Ethiopia, Malawi, and Tanzania. In addition, Uganda and Zimbabwe have a causal relationship from air transport to GDP. The Fisher test statistics results show that in the low-income countries, there is a unidirectional causal relationship between GDP and air transport (from GDP to AT) at the $1 \%$ significance level.

\section{Conclusion}

In this study, the causal relationship between air transport and GDP was examined using two different methods based on the income level of the countries. The first of 
these methods is the bootstrap-based panel causality analysis developed by Kónya (2006), which factors in the cross-sectional dependence and heterogeneity. The second is the panel causality method developed by Emirmahmutoğlu \& Köse (2011), which uses meta-analysis of composite heterogeneous panels. Representing four different levels of income, a total of 70 countries selected on the basis of data accessibility were included in the analysis covering the period of 1990-2016.

Kónya (2006) panel causality findings indicate that, for two countries in the highincome country group, there is a causal relationship directed from GDP to air transport. In this country group, no causality from air transport to GDP could be established. In the upper-middle-income country group, one country has causality running from GDP to air transport, one from air transport to GDP, and one has a bidirectional causal relationship. In the lower-middle-income country group, three countries have causality with direction from GDP to air transport, and two countries have causality running from air transport to GDP. Finally, in the lowincome country group, two countries exhibit a causal relationship running from GDP to air transport, and three countries have this causality running from air transport to GDP. Proportionally speaking, $10 \%$ of the countries in the highincome and upper-middle-income groups, $15 \%$ of the countries in the lowermiddle-income group, and $20 \%$ of the low-income group have causality running from GDP to air transport. These ratios indicate that as the income level declines, the number of countries with a GDP-to-air transport type causal relationship proportionally increases. Similarly, there are only two countries with air transportto-GDP type causal relationship in the high-income and upper-middle-income groups. However, this number rises to eight in the lower-middle-income and lowincome country groups (although the number of countries included in the sampling is lower). Therefore, as the income level of the countries decreases, the number of causal relationships running from air transport to GDP is observed to increase.

When the Emirmahmutoğlu \& Köse (2011) panel causality analysis results are examined, it is clear that in the high-income country group, there is a causal relationship from GDP to air transport in seven countries and from GDP to air transport in one country. In one of the countries, there is bidirectional causality from GDP to air transport as well as from GDP to air transport. Analyzing the Fisher test statistics values for all the countries in the panel, it is noticed that there is a unidirectional causal relationship from GDP to air transport at the 1\% significance level in the high-income country group. In the upper-middle-income country group, six countries have a causal relationship from GDP to air transport and one country has it from air transport to GDP. In two countries, a bidirectional causal relationship has been identified. At this level of income, the Fisher test statistics values for the country group indicate the presence of a bidirectional causal 
relationship from GDP to air transport as well as from air transport to GDP, with significance of $1 \%$ and $5 \%$, respectively. In the lower-middle-income country group, in three countries there is a causal relationship from GDP to air transport, and in two countries from air transport to GDP. Two of the countries in this group have a bidirectional causal relationship both from GDP to air transport and from GDP to air transport. For all countries in the panel, the Fisher test statistics values through which the causal relationship was analyzed demonstrate that a bidirectional causal relationship at a level of $1 \%$ significance exists in the lower-middle-income country group. Finally, in the low-income country group, the causality runs from GDP to air transport in three countries, while it runs from air transport to GDP in two of them. Fisher test statistics values for the country group at this income level point to the presence of a unidirectional causal relationship from GDP to air transport at the $1 \%$ significance level.

Some countries stand out in both empirical analyzes by demonstrating both a causal relationship running from GDP to air transport and from air transport to GDP. Thus, the existence of a GDP-to-air transport causal relationship in Iceland, United Arab Emirates, Brazil, Bolivia and Malawi has been proven by both causality analyses. Furthermore, both causality analyses have also confirmed that Bangladesh, Cameroon, Morocco and Zimbabwe have a causal relationship running from air transport to GDP. Most notably, the countries for which air transport-to-GDP causality has been verified in both empirical analyses belong to the lower-middle- income and low-income country groups, which supports the hypothesis that especially in the countries with below-average income level, air transport has an effect on economic growth.

\section{References}

Aderamo, A.J. (2010) Demand for Air Transport in Nigeria. Journal of Economics. [Online] 1 (1), 23-31. Available from: doi:10.1080/09765239.2010.11884921.

Alperovich, G. \& Machnes, Y. (1994) The role of wealth in the demand for international air travel. Journal of Transport Economics and Policy. [Online] 28 (2), 163-173. Available from: doi:10.2307/20053033.

Anfofum, A.A., Saheed, S.Z. \& Iluno, C. (2015) Air Transportation Development and Economic Growth in Nigeria. Journal of Economics and Sustainable Development. 6 (2), $1-11$.

Ba-Fail, A.O., Abed, S.Y. \& Jasimuddin, S.M. (2000) The Determinants of Domestic Air Travel Demand in the Kingdom of Saudi Arabia. Journal of Air Transportation World Wide. 5 (2), $72-86$.

Baikgaki, O.A. \& Daw, O.D. (2013) The determinants of domestic air passenger demand in the Republic of South Africa. Mediterranean Journal of Social Sciences. [Online] 4 
(13), 389-396. Available from: doi:10.5901/mjss.2013.v4n13p389.

Baker, D., Merkert, R. \& Kamruzzaman, M. (2015) Regional aviation and economic growth: Cointegration and causality analysis in Australia. Journal of Transport Geography. [Online] (43), 140-150. Available from: doi:10.1016/j.jtrangeo.2015.02.001.

Bal, H., Manga, M. \& Gümüş Akar, P. (2017) Havacılık Sektörü ve Ekonomik Büyüme: Türkiye Örneği. Akademik ve Sosyal Araştırmalar Dergisi. [Online] 5 (45), 353-366. Available from: doi:10.16992/ASOS.12189.

Beyzatlar, M.A., Karacal, M. \& Yetkiner, H. (2014) Granger-causality between transportation and GDP: A panel data approach. Transportation Research Part A: Policy and Practice. [Online] (63), 45-55. Available from: doi:10.1016/j.tra.2014.03.001.

Breusch, T.S. \& Pagan, A.R. (1980) The Lagrange Multiplier Test and its Applications to Model Specification in Econometrics. The Review of Economic Studies. [Online] 47 (1), 239-253. Available from: doi:10.2307/2297111.

Brida, G., Lanzilotta, B., Brindis, M. \& Rodríguez, S. (2014) Long-run relationship between economic growth and passenger air transport in Mexico. [Online]. Available from: http://www.iesta.edu.uy/wp-content/uploads/2015/03/ddt_04_20141.pdf.

Büberkökü, Ö. (2016) Tourism Development and Economic Growth: A Global Analysis Based on Panel Causality and Co-Integration Tests Robust to Cross-Section Dependency. Ekonomik Yaklaşım. [Online] 27 (100), 177-206. Available from: doi:10.5455/ey.35940.

Chi, J. \& Baek, J. (2013) Dynamic relationship between air transport demand and economic growth in the United States: A new look. Transport Policy. [Online] (29), 257-260. Available from: doi:10.1016/j.tranpol.2013.03.005.

Emirmahmutoğlu, F. \& Köse, N. (2011) Testing for Granger causality in heterogeneous mixed panels. Economic Modelling. [Online] 28 (3), 870-876. Available from: doi:10.1016/j.econmod.2010.10.018.

Fernandes, E. \& Pacheco, R.R. (2010) The causal relationship between GDP and domestic air passenger traffic in Brazil. Transportation Planning and Technology. [Online] 33 (7), 569-581. Available from: doi:10.1080/03081060.2010.512217.

Fisher, R.A. (1932) Statistical Methods for Research Workers. 4. Edinburgh, Oliver and Boyd.

Göçer, İ. (2013) Teknolojik İlerlemenin Belirleyicileri: NIC Ülkeleri için Panel Eşbütünleşme ve Panel Nedensellik Analizleri. Maliye ve Finans Yazıları. 1 (100), $116-141$.

Gözbaşı, O. (2015) Hisse Senedi Piyasası Gelişimi ve Ekonomik Büyüme Etkileşimi: Gelişmekte Olan Ülkeler Örneği. Eskişehir Osmangazi Üniversitesi İktisadi ve İdari Bilimler Dergisi. 10 (2), 269-284.

Gümüş, F.B. \& Koç, M. (2015) Ülkelerin Finansal Gelişmişlikleri İle Enerji Tüketimleri Arasındaki İlişki: Dört Kıta Örneği. Süleyman Demirel Üniversitesi İktisadi ve İdari Bilimler Fakültesi Dergisi. 20 (2), 151-164.

Hakim, M.M. \& Merkert, R. (2016) The causal relationship between air transport and economic growth: Empirical evidence from South Asia. Journal of Transport 
Geography. [Online] (56), 120-127. Available from: doi:10.1016/j.jtrangeo.2016.09.006.

Hu, Y., Xiao, J., Deng, Y., Xiao, Y., et al. (2015) Domestic air passenger traffic and economic growth in China: Evidence from heterogeneous panel models. Journal of Air Transport Management. [Online] (42), 95-100. Available from: doi:10.1016/j.jairtraman.2014.09.003.

Hutchinson, B.G. (1993) Analyses of canadian air travel demands. Journal of Transportation Engineering. [Online] 119 (2), 301-316. Available from: doi:10.1061/(ASCE)0733-947X(1993)119:2(301).

Kar, M., Nazlığlu, Ş. \& Ağır, H. (2011) Financial development and economic growth nexus in the MENA countries: Bootstrap panel granger causality analysis. Economic Modelling. [Online] 28 (1), 685-693. Available from: doi:10.1016/j.econmod.2010.05.015.

Kılıç, Y., Buğan, M.F. \& Özbezek, D. (2016) Asimetrik Bilgi ve Sinyal Teorisi: Temettü ve Kazanç İlişkisinde Panel Nedensellik Yaklaşımı. Gaziantep University Journal of Social Sciences. [Online] 15 (4), 1132-1145. Available from: doi:10.21547/jss.265502.

Kónya, L. (2006) Exports and growth: Granger causality analysis on OECD countries with a panel data approach. Economic Modelling. [Online] 23 (6), 978-992. Available from: doi:10.1016/j.econmod.2006.04.008.

Marazzo, M., Scherre, R. \& Fernandes, E. (2010) Air transport demand and economic growth in Brazil: A time series analysis. Transportation Research Part E: Logistics and Transportation Review. [Online] 46 (2), 261-269. Available from: doi:10.1016/j.tre.2009.08.008.

Mehmood, B. \& Shahid, A. (2014) Aviation Demand and Economic Growth in the Czech Republic: Cointegration Estimation and Causality Analysis. Statistika: Statistics and Economy Journal. 94 (1), 54-63.

Mukkala, K. \& Tervo, H. (2013) Air transportation and regional growth: Which way does the causality run? Environment and Planning A: Economy and Space. [Online] 45 (6), 1508-1520. Available from: doi:10.1068/a45298.

Nisansala, N. \& Mudunkotuwa, M. (2015) A Multivariate Co-integration Analysis of Air Passenger Movement: Empirical Evidence from in Sri Lanka. In: 8th International Research Conference. [Online]. 2015 Sri Lanka, General Sir John Kotelawala Defence University. pp. 275-282. Available from: http://ir.kdu.ac.lk/handle/345/1558.

Pesaran, M.H. (2004) General Diagnostic Tests for Cross Section Dependence in Panels. Cambridge Working Papers in Economics No: 0435.

Pesaran, M.H., Ullah, A. \& Yamagata, T. (2008) A bias-adjusted LM test of error crosssection independence. The Econometrics Journal. [Online] 11 (1), 105-127. Available from: doi:10.1111/j.1368-423X.2007.00227.x.

Profillidis, V. \& Botzoris, G. (2015) Air passenger transport and economic activity. Journal of Air Transport Management. [Online] (49), 23-27. Available from: doi:10.1016/j.jairtraman.2015.07.002.

The World Bank (2018) World Development Indicators. [Online]. 2018. Available from: https://databank.worldbank.org/indicator/NY.GDP.PCAP.CD/1ff4a498/Popular- 
Indicators [Accessed: 18 January 2018].

Toda, H.Y. \& Yamamoto, T. (1995) Statistical inference in vector autoregressions with possibly integrated processes. Journal of Econometrics. [Online] 66 (1), 225-250. Available from: doi:10.1016/0304-4076(94)01616-8.

Topallı, N. (2016) Doğrudan Sermaye Yatırımları, Ticari Dışa Açıklık ve Ekonomik Büyüme Arasındaki İlişki: Türkiye ve BRICS Ülkeleri Örneği. Doğuş Üniversitesi Dergisi. [Online] 17 (1), 83-95. Available from: doi:10.31671/dogus.2018.44.

Zeren, F. \& Ergün, S. (2013) Ticari Açıklık ve Kamu Büyüklüğü İlişkisi: Panel Nedensellik Testi. Atatürk Üniversitesi İktisadi ve İdari Bilimler Dergisi. 27 (4), 229-240. 